\title{
Genetic variation in the first intron and exon of the myostatin gene in several Indonesian cattle populations
}

\author{
Peni Wahyu Prihandini ${ }^{1}$, Almira Primasari ${ }^{1}$,, Aryogi Aryogi $^{1}$ (D), Jauhari Efendy ${ }^{1}$, Muchamad Luthfi $^{1}$ (D), \\ Dicky Pamungkas ${ }^{1}$ id and Dwi Nur Happy Hariyono²
}

1. Beef Cattle Research Institute of Grati, Pasuruan, Indonesia; 2. Department of Animal Science, Faculty of Agriculture, Universitas Khairun, Ternate, Indonesia.

Corresponding author: Peni Wahyu Prihandini, e-mail: peniprihandini@pertanian.go.id

Co-authors: AP: almira@pertanian.go.id, AA: aryogi@pertanian.go.id, JE: jauhariefendy@pertanian.go.id, ML: muchamadluthfi@pertanian.go.id, DP: dickypamungkas@pertanian.go.id, DNHH: d.nur.happy@unkhair.ac.id Received: 11-12-2020, Accepted: 30-03-2021, Published online: 19-05-2021

doi: www.doi.org/10.14202/vetworld.2021.1197-1201 How to cite this article: Prihandini PW, Primasari A, Aryogi A, Efendy J, Luthfi M, Pamungkas D, Hariyono DNH (2021) Genetic variation in the first intron and exon of the myostatin gene in several Indonesian cattle populations, Veterinary World, 14(5): 1197-1201.

\begin{abstract}
Background and Aim: Myostatin (MSTN), a member of the transforming growth factor- $\beta$ family, is a negative regulator of muscle mass. This study aimed to detect the genetic variation of the $1160 \mathrm{bp}$ fragment of exon 1 and part of intron 1 of the MSTN gene in several cattle populations raised in Indonesia.
\end{abstract}

\begin{abstract}
Materials and Methods: Polymerase chain reaction products of the MSTN gene amplified from 92 animals representing 10 cattle populations (Peranakan Ongole [PO], Belgian Blue x PO cross, Rambon, PO x Bali cross, Jabres, Galekan, Sragen, Donggala, Madura, and Bali) were sequenced, compared, and aligned with bovine MSTN of Bos taurus (GenBank Acc. No. AF320998.1) and Bos indicus (GenBank Acc. No. AY794986.1).

Results: Four nucleotide substitutions (nt 1045 and 1066 in intron 1; nt 262 and 418 in exon 1) and two indels (nt 807 and 869 in intron 1) were synonymous mutations. Among these substitutions, only the nt $262 \mathrm{G}>\mathrm{C}$ and nt $418 \mathrm{~A}>\mathrm{G}$ loci were polymorphic in all populations, except Bali cattle. The frequencies of the nt 262C (0.82) and nt 418A (0.65) alleles were highest. For the nt $262 \mathrm{G}>\mathrm{C}$ locus, the $\mathrm{CC}$ genotype had the highest frequency $(0.66)$ followed by GC $(0.30)$ and $\mathrm{CC}(0.03)$. For the nt 418A $>$ G locus, the AG genotype had the highest frequency (0.52) followed by AA (0.39) and GG (0.09).
\end{abstract}

Conclusion: The results, showing genetic variations in exon 1 and intron 1 of the MSTN gene, might be helpful for future association studies.

Keywords: beef cattle, double muscling, myostatin gene, polymorphisms, single-nucleotide polymorphism.

\section{Introduction}

Genetic improvement for economically important traits in livestock depends primarily on selective breeding using superior phenotypes. Current technologies using marker-assisted selection (MAS) enable scientists to improve the accuracy and efficiency of traditional selection methods and enhance the understanding of DNA polymorphisms that affect animal production traits [1]. If a single-nucleotide polymorphism (SNP) affects particular traits of interest, it could be used for MAS in livestock breeding programs [2]. Therefore, knowledge of genetic polymorphisms that are significantly associated with production traits of farm animals is of great interest to animal breeders.

In this study, myostatin (MSTN) was examined as a possible genetic marker in cattle breeding. The MSTN gene is a member of the transforming growth factor- $\beta$ family, which acts as a negative regulator

Copyright: Prihandini, et al. Open Access. This article is distributed under the terms of the Creative Commons Attribution 4.0 International License (http://creativecommons.org/licenses/ by/4.0/), which permits unrestricted use, distribution, and reproduction in any medium, provided you give appropriate credit to the original author(s) and the source, provide a link to the Creative Commons license, and indicate if changes were made. The Creative Commons Public Domain Dedication waiver (http:// creativecommons.org/publicdomain/zero/1.0/) applies to the data made available in this article, unless otherwise stated. of skeletal muscle mass deposition and plays an important role in mammalian postnatal muscle development $[3,4]$. The bovine $M S T N$ gene is located at $3.1 \mathrm{cM}$ (centimorgan) of the centromeric region on chromosome 2 (BTA2), next to TGLA44 microsatellites [5-7]. MSTN-deficient animals exhibit an increase in skeletal muscle mass with both hyperplasia and hypertrophy. This increased muscle mass results from the influence of MSTN on cell cycle control genes that cause myogenic progenitor cells to withdraw from the cell cycle permanently [8]. Furthermore, MSTN is an inhibitor of progenitor proliferation of skeletal muscle cells during animal development until the formation of skeletal muscle size after birth [9]. Mutations in the MSTN gene can affect the proper regulation of skeletal muscle mass, which is important for improved meat production traits. Many previous studies have investigated genetic variations of the MSTN gene not only in cattle $[3,6,10-14]$, but also in other livestock species, including goats [15], geese [16], chickens [17], and sheep [18]. Several cattle breeds are characterized by a double-muscling (DBM) phenotype, which increases muscle mass due to loss-of-function mutations in bovine MSTN [3,10,19,20]. In Belgian Blue cattle, a DBM phenotype is characterized by an 11 
bp deletion (c.821 831del11) in the third exon [3,6], which has also been found in Asturiana de Los Valles, Blonde d'Aquitaine, Limousine, Parthenaise, and Rubia Gallega cattle breeds $[6,10]$. In Piedmontese cattle MTSN, a missense mutation in exon 3 (c.938 $\mathrm{G}>\mathrm{A}$ ) changes a cysteine residue to a tyrosine, causing a DBM phenotype [10]. The same mutation has also been identified in Gascon cattle [10,12].

Up to now, few studies have investigated the MSTN variations in Indonesian cattle. Khasanah et al. [13] only investigated the promoter region of bovine MSTN in Bali cattle, while Anwar et al. [21] only investigated the F94L loci of bovine MSTN. To date, there is no literature available on the polymorphisms of the MSTN gene in several Indonesian local cattle types, such as Donggala, Galekan, Sragen, and Madura, analyzed in the present study. Furthermore, because of its important functions, MSTN is considered a candidate gene for growth-related traits in meat-producing animal species $[13,16,22]$.

Therefore, this study investigated the genetic polymorphisms of the MSTN gene in several cattle populations raised in Indonesia.

\section{Materials and Methods}

\section{Ethical approval}

The experimental procedures were carried out following the guidelines established by the Ministry of Agriculture of Indonesia. The Indonesian Agency for Agricultural Research and Development approved the procedures (Balitbangtan/Lolitsapi/Rm/09/2020).

\section{Study period and location}

The study was conducted from April to September 2019. The Peranakan Ongole (PO), Belgian Blue $\times$ $\mathrm{PO}$ cross $(\mathrm{BP}), \mathrm{PO} \times$ Bali cross $(\mathrm{PB})$, and Bali (BL) cattle were obtained from the Beef Cattle Research Institute of Grati, East Java, while the Rambon (RM), Jabres (JB), Galekan (GK), Sragen (SR), Donggala (DG), and Madura (MD) cattle were collected from Banyuwangi of East Java Province, Brebes of Central Java Province, Trenggalek of East Java Province, Sragen of Central Java Province, Donggala of Central Sulawesi Province, and Pamekasan of East Java Province, respectively. Samples were processed at the Indonesian Beef Cattle Research Station.

\section{Animals and sample collection}

This study involved 92 animals from various cattle populations farmed in Indonesia. Breeds evaluated included PO ( $\mathrm{n}=10), \mathrm{BP}(\mathrm{n}=8), \mathrm{RM}(\mathrm{n}=10), \mathrm{PB}(\mathrm{n}=10)$, JB $(n=10)$, GK $(n=10)$, SR $(n=10)$, DG $(n=9)$, MD $(n=10)$, and BL $(n=5)$. All the studied breeds, except BP and $\mathrm{PB}$ crosses, have been identified as local Indonesian cattle by the Ministry of Agriculture of the Republic of Indonesia [23] and are included in the national genetic resources program due to their economic importance. Blood samples, taken from the jugular vein, were collected in $3 \mathrm{~mL}$ tubes containing EDTA as an anticoagulant and kept at $4^{\circ} \mathrm{C}$ until analyzed.
DNA preparation and polymerase chain reaction (PCR) amplification

Genomic DNA was extracted from the blood samples using a gSYNCTM DNA extraction kit (Geneaid, New Taipei City, Taiwan) and stored at $-20^{\circ} \mathrm{C}$ before analysis. A fragment of $1160 \mathrm{bp}$ covering part of intron 1 and exon 1 of bovine MSTN was amplified using PCR. The primer sequences selected were MSTN_F, 5'-AGTATAAAAGATTCACTGGTGTGGC-3' and MSTN_R, 5'-TGTGTTTACTTCCTTATTGCTCTT ACTA-3' [11] based on the bovine MSTN sequence (GenBank Acc. No. AF320998). The PCR reaction was performed using SensoQuest (Germany) and made up of $2 \mu \mathrm{L}$ of template DNA (10-100 ng), $0.5 \mu \mathrm{L}$ of each primer $(0.25 \mu \mathrm{M}), 12.5 \mu \mathrm{L}$ PCR kit diluent $(2 \mathrm{x}$ My Taq HS Red Mix gSYNCTMPCR Kit-BiolineLondon), and $9.5 \mu \mathrm{L} \mathrm{ddH}_{2} \mathrm{O}$ for a total volume of $25 \mu \mathrm{L}$. The thermal cycling included an initial denaturation at $95^{\circ} \mathrm{C}$ for $5 \mathrm{~min}$, followed by 35 cycles of $94^{\circ} \mathrm{C}$ for $45 \mathrm{~s}, 57^{\circ} \mathrm{C}$ for $45 \mathrm{~s}$, and $72^{\circ} \mathrm{C}$ for $60 \mathrm{~s}$, with a final extension step at $72^{\circ} \mathrm{C}$ for $5 \mathrm{~min}$. The PCR products were sequenced using an ABI 3730xl genetic analyzer (Applied Biosystems, Foster City, CA, USA).

\section{Statistical analysis}

The MSTN gene sequencing results were manually checked and edited using BioEdit software [24] and aligned to the reference bovine MSTN (Bos taurus, GenBank Acc. No. AF320998.1 and Bos indicus, GenBank Acc. No. AY794986.1) using the ClustalW program [25]. Allelic and genotypic frequencies and Chi-square test were performed using POPGENE 1.32 software (https://sites.ualberta.ca/ fyeh/index. html) [26].

\section{Results}

The $1160 \mathrm{bp}$ fragment, including part of intron 1 and exon 1, of the bovine MSTN gene, was successfully sequenced for 92 individual animals from 10 cattle populations in Indonesia. $B$. indicus cattle breeds are prevalent in Indonesia, but several breeds come from a mixture of $B$. indicus and $B$. taurus. For that reason, the resulted sequences were compared to zebrine and bovine MSTN sequences deposited to GenBank (B. indicus Acc. No. AY794986 and B. taurus Acc. No. AF320998). By alignment of those sequences, we observed four nucleotide substitutions (nt 1045 and 1066 in intron 1; nt 262 and 418 in exon 1) and two indels (nt 807 and 869 in intron 1), which were synonymous mutations (Table-1). However, only nt 262 and 418 were polymorphic across the Indonesian cattle populations (Figure-1). These two SNPs generated three genotypes each, which were homozygote $\mathrm{GG}$, heterozygote $\mathrm{GC}$, and homozygote $\mathrm{CC}$ for the SNP $(\mathrm{G}>\mathrm{C})$ at nt 262, and homozygote AA, heterozygote $\mathrm{AG}$, and homozygote $\mathrm{GG}$ for the SNP $(\mathrm{A}>\mathrm{G})$ at nt 418 .

Table- 2 shows the allelic and genotypic frequencies and Chi-square test results of the MSTN loci in the 10 cattle populations (nt $262 \mathrm{G}>\mathrm{C}$ locus) and Table-3 


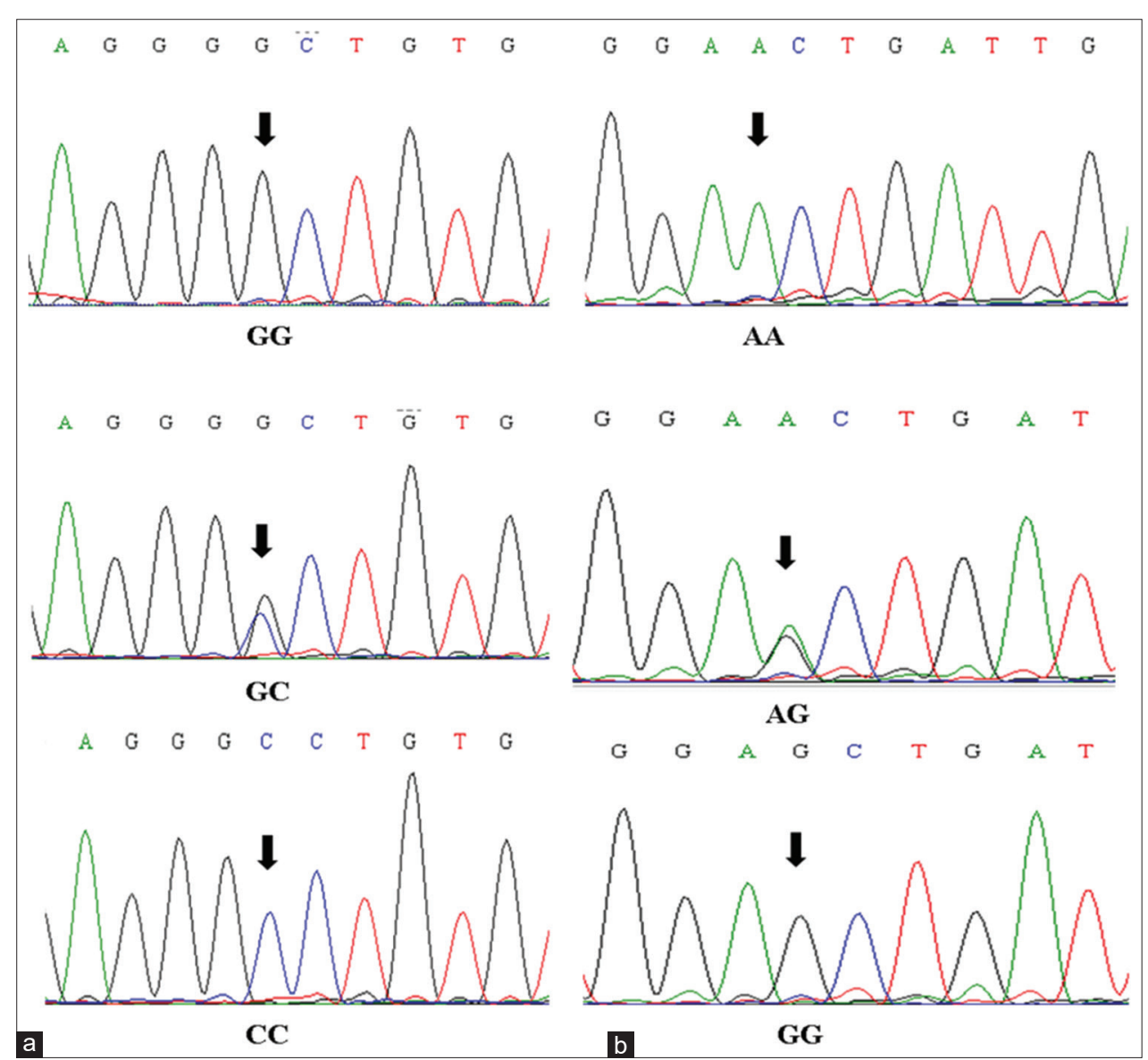

Figure-1: Chromatogram of the MSTN gene exon 1. (a) Variation at nt 216 (G>C transition), from top to bottom: Homozygote GG, heterozygote GC, and homozygote CC. (b) Variation at nt 418 (A>G transition), from top to bottom: Homozygote AA, heterozygote $A G$, and homozygote GG.

Table-1: Polymorphisms of myostatin gene detected in this study.

\begin{tabular}{lllll}
\hline Base position (AF320998.1) & Location & $\begin{array}{l}\text { Bos taurus sequence } \\
\text { (AF320998.1) }\end{array}$ & $\begin{array}{l}\text { Bos indicus sequence } \\
\text { (AY794986.1) }\end{array}$ & Indonesian cattle \\
\hline 262 & Exon 1 & G & G & G/C \\
418 & & A & G & A/G \\
807 & Intron 1 & T & - & - \\
869 & & Insertion & T & - \\
1045 & & T & - & T \\
1066 & & G & T & G \\
\hline
\end{tabular}

Table-2: Allelic and genotypic frequencies and Chi-square test of the MSTN nt $262 \mathrm{G}>\mathrm{C}$ in the studied populations.

\begin{tabular}{|c|c|c|c|c|c|c|c|}
\hline \multirow[t]{2}{*}{ Population } & \multicolumn{3}{|c|}{ Genotype } & \multicolumn{2}{|c|}{ Allele } & \multirow[t]{2}{*}{$\chi^{2}$ (HWE) } & \multirow[t]{2}{*}{ p-value } \\
\hline & GG & GC & CC & G & C & & \\
\hline $\mathrm{PO}$ & 0.50 & 0.30 & 0.20 & 0.65 & 0.35 & 1.5879 & 0.208 \\
\hline BP & 0.88 & 0.12 & 0.00 & 0.94 & 0.06 & 0.0000 & 0.000 \\
\hline RM & 0.50 & 0.50 & 0.00 & 0.75 & 0.25 & 0.8571 & 0.355 \\
\hline PB & 0.60 & 0.40 & 0.00 & 0.80 & 0.20 & 0.4500 & 0.502 \\
\hline JB & 0.80 & 0.20 & 0.00 & 0.90 & 0.10 & 0.0588 & 0.808 \\
\hline GK & 0.60 & 0.40 & 0.00 & 0.80 & 0.20 & 0.4500 & 0.502 \\
\hline SR & 0.80 & 0.20 & 0.00 & 0.90 & 0.10 & 0.0588 & 0.808 \\
\hline DG & 0.33 & 0.56 & 0.11 & 0.61 & 0.39 & 0.1108 & 0.739 \\
\hline MD & 0.80 & 0.20 & 0.00 & 0.90 & 0.10 & 0.0588 & 0.808 \\
\hline $\mathrm{BL}$ & 1.00 & 0.00 & 0.00 & 1.00 & 0.00 & - & - \\
\hline All & 0.66 & 0.30 & 0.03 & 0.82 & 0.18 & 0.0021 & 0.963 \\
\hline
\end{tabular}

$\mathrm{HWE}=$ Hardy-Weinberg equilibrium, $\mathrm{PO}=$ Peranakan Ongole cattle, $\mathrm{BP}=$ Belgian Blue $\mathrm{X} \mathrm{PO}$ cross cattle, $\mathrm{RM}=$ Rambon cattle, $\mathrm{PB}=\mathrm{PO} \times$ Bali cross cattle, $\mathrm{JB}=$ Jabres cattle, $\mathrm{GK}=$ Galekan cattle, $\mathrm{SR}=$ Sragen cattle, $\mathrm{DG}=$ Donggala cattle, MD=Madura cattle, BL=Bali cattle. (nt $418 \mathrm{~A}>\mathrm{G}$ locus). In the overall populations, the frequencies of $\mathrm{nt} 262 \mathrm{C}(0.82)$ and $\mathrm{nt} 418 \mathrm{~A}(0.65)$ alleles were the highest. For the nt $262 \mathrm{G}>\mathrm{C}$ locus, the CC genotype had the highest frequency (0.66) followed by GC (0.30) and CC (0.03) genotypes. For the nt $418 \mathrm{~A}>\mathrm{G}$ locus, $\mathrm{AG}$ genotypes had the highest frequency (0.52) followed by AA (0.39) and GG (0.09) genotypes. Interestingly, there was no variation in Bali cattle for both loci. All the tested animals belonged to the GG genotype for the $n t 262 \mathrm{G}>\mathrm{C}$ locus and the AA genotype for the nt $418 \mathrm{~A}>\mathrm{G}$ locus. The Chi-square test showed that all the studied populations, except BP and BL, were found to be in Hardy-Weinberg equilibrium for both loci $(\mathrm{p}>0.05)$.

\section{Discussion}

Genetic improvement of farm animals has gained much attention in recent years, particularly for growth 
Table-3: Allelic and genotypic frequencies and Chi-square test of the MSTN nt 418A>G in the studied populations.

\begin{tabular}{|c|c|c|c|c|c|c|c|}
\hline \multirow[t]{2}{*}{ Population } & \multicolumn{3}{|c|}{ Genotype } & \multicolumn{2}{|c|}{ Allele } & \multirow[t]{2}{*}{$\chi^{2}$ (HWE) } & \multirow[t]{2}{*}{ p-value } \\
\hline & AA & AG & GG & A & G & & \\
\hline $\mathrm{PO}$ & 0.30 & 0.50 & 0.20 & 0.55 & 0.45 & 0.0182 & 0.893 \\
\hline BP & 0.50 & 0.50 & 0.00 & 0.75 & 0.25 & 0.6364 & 0.425 \\
\hline RM & 0.20 & 0.70 & 0.10 & 0.55 & 0.45 & 1.3136 & 0.252 \\
\hline PB & 0.40 & 0.60 & 0.00 & 0.70 & 0.30 & 1.4835 & 0.223 \\
\hline $\mathrm{JB}$ & 0.20 & 0.70 & 0.10 & 0.55 & 0.45 & 1.3136 & 0.252 \\
\hline GK & 0.50 & 0.40 & 0.10 & 0.70 & 0.30 & 0.1055 & 0.745 \\
\hline SR & 0.40 & 0.60 & 0.00 & 0.70 & 0.30 & 1.4835 & 0.223 \\
\hline DG & 0.33 & 0.56 & 0.11 & 0.61 & 0.39 & 0.1108 & 0.739 \\
\hline MD & 0.40 & 0.40 & 0.20 & 0.60 & 0.40 & 0.4870 & 0.485 \\
\hline $\mathrm{BL}$ & 1.00 & 0.00 & 0.00 & 1.00 & 0.00 & - & - \\
\hline All & 0.39 & 0.52 & 0.09 & 0.65 & 0.35 & 1.9263 & 0.165 \\
\hline
\end{tabular}

$\mathrm{HWE}=\mathrm{Hardy}$-Weinberg equilibrium, $\mathrm{PO}=$ Peranakan Ongole cattle, $\mathrm{BP}=$ Belgian Blue $\mathrm{X} \mathrm{PO}$ cross cattle, $\mathrm{RM}=$ Rambon cattle, $\mathrm{PB}=\mathrm{PO} \times$ Bali cross cattle, JB=Jabres cattle, $\mathrm{GK}=$ Galekan cattle, $\mathrm{SR}=$ Sragen cattle, $\mathrm{DG}=$ Donggala cattle, $\mathrm{MD}=$ Madura cattle, $\mathrm{BL}=$ Bali cattle.

performance and carcass traits which are economically important domestic animal characteristics, due to their contributions to farm profitability. Many studies have explored candidate genes or loci related to these economic traits in many domestic animals over the past decades. For instance, MSTN is a vital candidate gene responsible for growth and carcass traits in cattle. Gene mutations that contribute to loss of MSTN function have been linked to the occurrence of DBM in cattle [10].

This study showed polymorphisms in part of intron 1 and exon 1 of the MSTN gene in Indonesian cattle sequences compared to the cited GenBank sequences (Table-1). All the mutations (nt 262, 418, $807,869,1045$, and 1066) observed in this study were synonymous and reported previously in Qinchuan and Red Angus cattle breeds [11]. Tantia et al. [27] sequenced the MSTN gene of Indian $B$. indicus breeds (i.e., Rathi, Deoni, Idduki, and Vatakara) and compared their sequences to B. taurus (GenBank Acc. AB076403). Their study found two SNPs in exon 1 of the MSTN gene, including nt 244 and nt 400, equal to nt 262 and nt 418 detected in the present study. It is notable that Tantia et al. [27] determined base position according to GenBank Acc. No. AB076403 of B. taurus, while the present study used GenBank Acc. No. AF320998.1 of B. taurus. Dunner et al. [12] detected two SNPs (nt $267 \mathrm{~A}>\mathrm{G}$ and $n t 324 \mathrm{C}>\mathrm{T}$ ) in exon 1 of the MSTN gene in some French breeds (Aubrac, Badaize, and Salers), of which nt 267 (GenBank Acc. No. AF019620.1) is equal to nt 418 identified in this study. A nucleotide substitution at nt 267 has also been reported previously in Nellore cattle [28]. The polymorphisms identified in this study provide data for future association research.

Several studies have pointed out six SNPs in the bovine MSTN gene responsible for a DBM phenotype, including nt 419 (del7-ins10) in Maine-Anjou cattle, nt $610(\mathrm{C} \rightarrow \mathrm{T})$ in Carolaise and Limousine cattle, nt
$676(\mathrm{G} \rightarrow \mathrm{T})$ in Maine-Anjou cattle, nt 821 (del11) in Asturiana de Los Valles, Belgian Blue, Limousine, Parthenaise, and Rubia Gallega cattle, nt $874(\mathrm{G} \rightarrow \mathrm{T})$ in Marchigiana cattle, and nt $938(\mathrm{G} \rightarrow \mathrm{A})$ in Gascon and Piedmontese cattle $[3,10,19,20]$. Unfortunately, the primers used in this study did not cover these loci. Haruna et al. [14] found seven nucleotide variations (c. $373+751 \mathrm{G}>\mathrm{T}$, c. $373+803 \mathrm{~T}>\mathrm{G}, \quad$ c. $373+877 \mathrm{~A}>\mathrm{G}$, c. $373+895 \mathrm{G}>\mathrm{C}, \quad$ c. $374-909 \mathrm{C}>\mathrm{T}, \quad$ c. $374-842 \mathrm{G}>\mathrm{C}$, c. $374-812 \mathrm{~A}>\mathrm{G}$ ) in intron 1 of MSTN in New Zealand cattle breeds, of which two variants (c.748-281C $>\mathrm{G}$ and c.748-352C $>\mathrm{T}$ ) have been reported in Qinchuan and Red Angus cattle [11]. In contrast to the results of this study, Haruna et al. [14] did not observe any nucleotide variation in exon 1 of the MSTN gene in New Zealand cattle.

\section{Conclusion}

Our preliminary study suggests polymorphisms in exon 1 and part of intron 1 of the MSTN gene in Indonesia cattle. Further studies are needed to evaluate the effects of these polymorphisms on growth-related traits in a larger sample size to create a selection tool for improved growth traits in breeding programs.

\section{Authors' Contributions}

PWP, AA, JE, ML, and DP designed the study and collected the samples. AP collected samples and performed laboratory analysis. DNHH analyzed the data and wrote the manuscript. All authors have read and approved the final manuscript.

\section{Acknowledgments}

This work was supported by grant from the Ministry of Agriculture of the Republic of Indonesia through the Agency of Agricultural Research and Development (SP DIPA-018.09.2.648720/2020).

\section{Competing Interests}

The authors declare that they have no competing interests.

\section{Publisher's Note}

Veterinary World remains neutral with regard to jurisdictional claims in published institutional affiliation.

\section{References}

1. Guo, P., Zhao, Z., Yan S, Li, J., Xiao H., Yang D., Zhao Y., Jiang P. and Yang R. (2016) PSAP gene variants and haplotypes reveal significant effects on carcass and meat quality traits in Chinese Simmental-cross cattle. Arch. Anim. Breed, 59(4): 461-468.

2. Kononoff, P.J., Defoor, P.J., Engler, M.J., Swingle, R.S., James, S.T. and Marquess, F.L.S. (2014) Impact of a leptin single nucleotide polymorphism and ractopamine hydrochloride on growth and carcass characteristics in finishing steers. J. Anim. Sci., 92(6): 2702-2707.

3. McPherron, A.C. and Lee, S.J. (1997) Double muscling in cattle due to mutations in the myostatin gene. Proc. Natl. Acad. Sci. U. S. A., 94(23): 12457-12461.

4. Aiello, D., Patel, K. and Lasagna, E. (2018) The myostatin 
gene: An overview of mechanisms of action and its relevance to livestock animals. Anim. Genet., 49(6): 505-519.

5. Charlier, C., Coppieters, W., Farnir, F., Grobet, L., Leroy, P.L., Michaux, C., Mni, M., Schwers, A., Vanmanshoven, P., Hanset, R. and Georges, M. (1995) The mh gene causing double-muscling in cattle maps to bovine chromosome 2. Mamm. Genome, 6(11): 788-792.

6. Grobet, L., Martin, L.J., Poncelet, D., Pirottin, D., Brouwers, B., Riquet, J., Schoeberlein, A., Dunner, S., Ménissier, F., Massabanda, J., Fries, R., Hanset, R. and Georges, M. (1997) A deletion in the bovine myostatin gene causes the double-muscled phenotype in cattle. Nat. Genet., 17(1): 71-74.

7. Smith, T.P., Lopez-Corrales, N.L., Kappes, S.M. and Sonstegard, T.S. (1997) Myostatin maps to the interval containing the bovine mh locus. Mamm. Genome, 8(10): 742-744.

8. Joulia, D., Bernardi, H., Garandel, V., Rabenoelina, F., Vernus, B. and Cabello, G. (2003) Mechanisms involved in the inhibition of myoblast proliferation and differentiation by myostatin. Exp. Cell. Res., 286(2): 263-275.

9. Grade, C.V.C., Mantovani, C.S. and Alvares, L.E. (2019) Myostatin gene promoter: Structure, conservation and importance as a target for muscle modulation. J. Anim. Sci. Biotechnol., 10: 32.

10. Kambadur, R., Sharma, M., Smith, T.P.L. and Bass, J.J. (1997) Mutations in myostatin (GDF8) in double-muscled Belgian Blue and Piedmontese cattle. Genome Res., 7(9): 910-915.

11. He, Y.I., Wu, Y.H., Quan, F.S., Liu, Y.G. and Zhang, Y. (2013) Comparative analysis of myostatin gene and promoter sequences of Qinchuan and Red Angus cattle. Genet. Mol. Res., 12(3): 3398-3406.

12. Dunner, S., Mi'randa, M.E., Amigues, Y., Cañón, J., Georges, M., Hanset, R., Williams, J. and Ménissier, F. (2003) Haplotype diversity of the myostatin gene among beef cattle breeds. Genet. Sel. Evol., 35(1): 103-118.

13. Khasanah, H., Gunawan, A., Priyanto, R., Ulum, M.F. and Jakaria, J. (2016) Polymorphism of myostatin (MSTN) promoter gene and its association with growth and muscling traits in Bali cattle. Med. Peternakan, 39(2): 95-103.

14. Haruna, I.L., Ekegbu, U.J., Ullah, F., AmirpourNajafabadi, H., Zhou, H. and Hickford, J.G.H. (2020) Genetic variations and haplotypic diversity in the myostatin gene of New Zealand cattle breeds. Gene, 740: 144400.

15. Dowidar, Y.A., El-Sayed, M.A., Elrefy, A.M. and Shoura, H.E. (2018) Detection of myostatin gene MSTN in some goat breeds (Capra hircus). J. Genet. Eng. Biotechnol., 16(2): 507-512.

16. Smołucha, G., Kozubska-Sobocinska, A., Koseniuk, A., Zukowski, K., Lisowski, M. and Grajewski, B. (2020) Polymorphism of the myostatin (MSTN) gene in Landes and Kielecka geese breeds. Animals, 10(1): 10.
17. Zhang, X.X., Ran, J.S., Lian, T., Li, Z.Q., Yang, C.W., Jiang, X.S., Du, H.R., Cui, Z.P. and Liu, Y.P. (2019) The single nucleotide polymorphisms of myostatin gene and their associations with growth and carcass traits in Daheng broiler. Braz. J. Poult. Sci., 21(3): 001-008.

18. Haren, H.I.H., Purwantini, D., Sumaryadi, M.Y. and Prayitno, P. (2020) Polymorphism at third exon of the myostatin gene and its association with growth and carcass traits in Batur sheep. Biodiversitas, 21(5): 2074-2078.

19. Cappuccio, I., Marchitelli, C. and Serracchioli, A. (1998) A G-T transversion introduces a stop codon at the mh locus in hypertrophy Marchigiana beef subjects. Anim. Genet., 29(1): 51.

20. Grobet, L., Poncelet, D., Royo, L.J., Brouwers, B., Pirottin, D., Michaux, C., Ménissier, F., Zanotti, M., Dunner, S. and Georges, M. (1998) Molecular definition of an allelic series of mutations disrupting the myostatin function and causing double-muscling in cattle. Mamm. Genome, 9(3): 210-213.

21. Anwar, S., Volkandari, S.D., Wulandari, A.S., Putra, W.P.B., Sophian, E. and Said, S. (2020) Detection of F94L mutation of the MSTN gene in four Indonesian local cattle breeds. $J$. Indones. Trop. Anim. Agric., 45(1): 7-14.

22. Khani, K., Abdolmohammadi, A., Foroutanifar, S. and Zebarjadi, A. (2017) Assessment of polymorphisms in myostatin gene and their allele substitution effects showed a weak association with growth traits in Iranian Markhoz goats. J. Agric. Sci., 155(3): 519-526.

23. MARI (Ministry of Agriculture Republic Indonesia). (2021) Directorate of Animal Breeding and Production. Available from: http://bibit.ditjenpkh.pertanian.go.id/jenis-rumpun/ sapi. Retrieved on 04-05-2021.

24. Hall, T. (1999) Bioedit: A biological sequence alignment editor and analysis program for windows 95/98/nt. Nucleic Acids Symp. Ser., 41(2): 95-98.

25. Thompson, J.D., Higgins, D.G. and Gibson, T.J. (1994) Clustal W: Improving the sensitivity of progressive multiple sequence alignment through sequence weighting, position-specific gap penalties and weight matrix choice. Nucleic Acids Res., 22(22): 4673-4680.

26. Yeh, F.C., Yang, R.C., Boyle, T.B.J., Ye, Z.H. and Mao, J.X. (1997) Popgene, the User Friendly Shareware for Population Genetic Analysis. Molecular Biology and Biotechnology Center, Alberta, Canada.

27. Tantia, M.S., Vijh, R.K., Kumar, S.T.B., Mishra, B. and Reecy, J.M. (2006) Comparative analysis of GDF 8 (myostatin) in Bos indicus and Bos taurus. DNA Seq., 17(4): 311-313.

28. Grisolia, A.B., D'Angelo, G.T., Porto Neto, L.R., Siqueira, F. and Garcia, J.F. (2009) Myostatin (GDF8) single nucleotide polymorphisms in Nellore cattle. Genet. Mol. Res., 8(3): 822-830. 